\title{
Rootstock for Stone Fruits-A New Prospective
}

\author{
Pramanick KK* \\ Department of agriculture, Indian Agricultural Research Institute, India
}

Submission: May 12, 2018; Published: July 05, 2018

${ }^{*}$ Corresponding author: Pramanick KK, Indian Agricultural Research Institute, Regional Station (Cereals \& Hoticultural Crops), Amartara Cottage, Cart Road, Shimla-171004 (H.P.), Tel/Fax: 0177-2655305/2808766,Email: kallolpramanick@gmail.com,kallol_pramanick@yahoo.co.in

\section{Importance}

Economic viability of a fruit production enterprise is linked directly to orchard productivity and management efficiency. To increase productivity and efficiency requires tree survival, managed vigor and increased marketable yields over the expected life span of the orchard. Several surveys have been undertaken to determine the relative importance of the various "problems" facing stone fruit industries around the world. The different problems associated with the rootstocks of stone fruits are soils having high bulk density, parasitic nematodes, root rot fungal pathogens other edaphic or replant but the major being incompatibility of the rootstock with the scion. In India, the restrictions for the cultivation of stone fruits are mainly due to lack of compatible rootstocks. The major production of stone fruits in India is in the North-Western Indian States of Jammu and Kashmir (J\&K), Himachal Pradesh (H.P.), Uttrakhand hills and to some extent in the North-Eastern Hills region.

\section{Different Rootstocks}

Different rootstocks have been reported for different problems in stone fruits. Additionally, many "problem" sites have more than one limitation and require that a new rootstock incorporate resistance to multiple problems for successful adaptation. In many cases, new rootstocks are probably best suited for regional or prescription/niche planting rather than broad use over a large industry. Regional testing is the only way to determine each rootstock's best adaptation. Priorities vary from one stone fruit crop to another. Several studies have shown that the rootstock requirement for apricots (P. armeniaca) and plum (P. domestica, $P$. salicina) are similar to the rootstock requirement of peach. For sweet cherry (P. avium), the first and foremost need in rootstocks is for size reduction followed by increased scion precocity and compatibility so sour cherry (P. cerasus), which has low inherent vigor (compared to sweet cherry) can be used as a rootstock for sweet chery. Fortunately, many stone fruit species can be budded onto other Prunus species. As a result, peaches, plums, apricots and almonds (P. amygdalus) often can be budded onto rootstocks developed for each other. In this way, progress made in developing water-logging tolerant rootstocks for plum also can be used advantageously as a rootstock for peaches, apricots or almonds.

Not all stone fruit scions are compatible with available Prunus rootstocks namely: $P$. cerasifera, $P$. cerasiferax $P$. munsoniana, $P$. domestica, P. insititia, P. americana, P. pumila, P. besseyi, $P$. spinosa, P. dulcis, P. amygdalusx P. persica, P. insititiax P. domestica, P. armeniaca, $P$. salicina, $P$. persica $x$ P. davidianaand $P$. amygdalusx P. nemared(P. persica $x$ P. davidiana) used as rootstocks for peach, plum, apricot and almond in different countries. Wild forms of peach, apricot, plum and almonds are also used as rootstock in India depending on varietal graft compatibility and soil types. Almond as rootstock shows better resistance to limestone and drought conditions, and peach induces tree vigour and nematode resistance, whereas, different plum species as rootstock are more resistant to water-logging and various diseases. Peach almond Titan Hybrids (Titan almond x Nemaguard hybrid seedling) namely: Red and Green Leaf Titan are extremely vigorous, resistant to nematode, tolerant to calcareous soil and cold. Guardian is another peach rootstock which exhibits nematode and peach tree short leaf resistance and moderatly cold hardy. Bailey is another hardy peach rootstock. Studies have suggested that a wide range of Prunus rootstocks resistant to nematode which includes Argot, P.S. Series Cadaman, Ishatara, Marianna 2624 and Garnem. In other countries, wild apricot selections namely: INRA Manihot and North African wild apricot are commonly used as rootstock. Apart from wild biotypes, seedlings or clonal selections of different species which are used as root stocks are Royal, Higgith, Siberian C, Rubira, Harrow Blood, GF 677, Marianna series, Myrobalan series, Damas GF 1869, Rutger's Red Leaf, St. Julien series, Myram, Nemaguard, Nemared, Lovell, Pixy, Citation, Brompton, Pershore, Julior, Flordaguard etc. Seeds of $P$. cerasoides easily germinate and commonly used as seedling rootstock for sweet cherry in India. P. cornutais a very good rootstock for cherry and has been found to be compatible.

Mazzard seedlings and F/12 produce larger tree as rootstock having longer life span. Mahaleb induces precocious bearing on scion cultivars and gives very good performance on light 
textured sandy to sandy loam or calcareous soil and even under water stress condition. Trees on these rootstocks are better in hardiness, survival and yield in comparison to Mazzard and Stockton Morello. In some countries, Mahaleb seedlings such as CEMA (C500) and Korponay seedling are commercially used. A new series under P. cerasus was raised from seeds of 'Weiroot 11' namely: 53, 72 and 158 (Stehr, 1998). Many rootstocks are in use in different countries evolved from P. cerasus namely: Edabriz, Weiroot 10, Weiroot 13, Weiroot 53, Weiroot 72 and Weiroot 158. Some other rootstocks are Gisela 5 (P. cerasusx $P$. canescens), Giesela 6 (P. cerasusx P. canescens), LC-52 [P.cerasusx (P.cerasusx P. maackii)], Colt (P.avium x P. psedocerasus) and OCR and $\mathrm{CAB}$ series. Graft union success is evaluated by the vigor, productivity and longevity of the scion. Some rootstocks might have undesirable influences on the scion including reduced fruit size, delayed leaf growth, and delayed ripening. Typically, several years after peach scions are grafted onto plum rootstocks the graft union develops a "shoulder" and trees topple over in high winds. Other signs of incompatibility include low scion vigor, shoot dieback, premature leaf drop, or excessive root suckering.

Major portion of the total stone fruits production in Himachal Pradesh is confined mainly to the mid hill region falling in the altitude range of 1000-1700 meters above mean sea level where the summer are moderately hot (31.8 to 34.80C) during May-June and winters are cold (2.4 to 3.70C) during DecemberJanuary. The average annual rainfall ranges from 100-130 cm, $90 \%$ of which is limited to two months of the monsoon (JulyAugust) and during the rest of the year plants remain under water stress. Most of the orchards are on sloppy land where irrigation is difficult to practice and due to scarcity of water and uneven distribution of rainfall throughout the growing season drought conditions are commonly prevalent, which results in poor fruit set, heavy fruit drop and sometimes even cause the death of the plants. Like majority of fruit crops, stone fruits are also multiplied clonally by grafting the scion cultivar on the desired rootstock and beneficial effects of rootstock on the grafted plant. Wild relatives of the stone fruits e.g. wild peach (Kateru), wild apricot (Chulli) and Behmi have remained the first choice as rootstock in case of stone fruits on commercial level and have adapted in this region for ages.

Thus, in India the productivity of peach, plum and apricot is 8.10 tonnes/hac, 5.7 tonnes/hac and 4.17 tonnes/hac respectively which is considerably low as compared to other countries where these fruits are grown commercially. Non-availability of good rootstocks suitable for the local climatic conditions for mid hills of Himachal Pradesh is one of the major reasons for the low productivity of these crops. Since there is huge variations available in form of wild peach (kateru), wild apricot (Chulli) and Behmi from which suitable clonal rootstock could be evolved which are suitable for the local climatic conditions and benefit the orcharding enterprise to a larger extent.

\section{The New Prospective}

A dwarf rootstock which is compatible to all the stone fruits has been studied at the regional station, Shimla of Indian Agricultural Research Institute and successful results have been reported. All the stone fruits likepeach, plum, apricot, almond and cherry of genus Prunus have been successfully grafted on Prunus persica. These have shown complete compatibility in terms of growth, vigour, fruit set and bearing habits as shown in Figure $1 \& 2$. It could be utilized in high density orcharding.
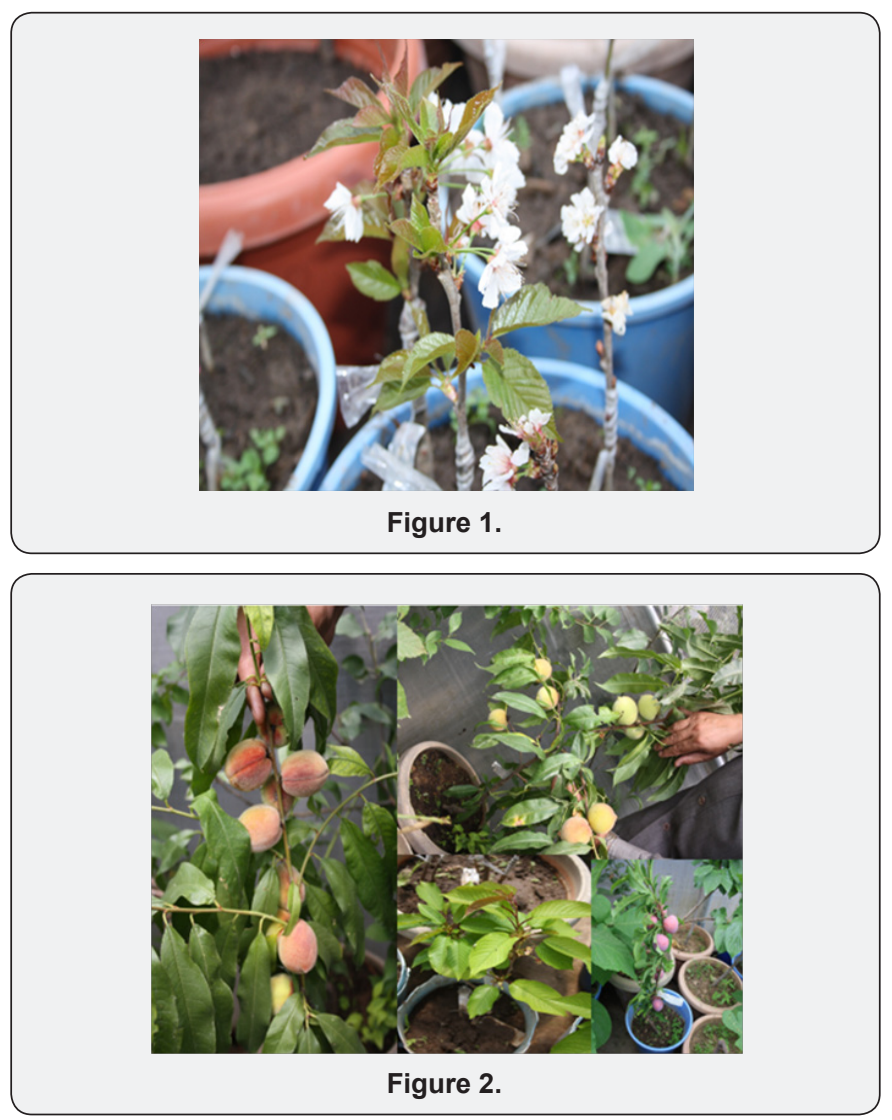
This work is licensed under Creative Commons Attribution 4.0 License DOI: 10.19080/JOJHA.2018.01.555574
- Quality Editorial service

- Swift Peer Review

- Reprints availability

- E-prints Service

- Manuscript Podcast for convenient understanding

- Global attainment for your research

- Manuscript accessibility in different formats ( Pdf, E-pub, Full Text, Audio)

- Unceasing customer service

Track the below URL for one-step submission https://juniperpublishers.com/online-submission.php 